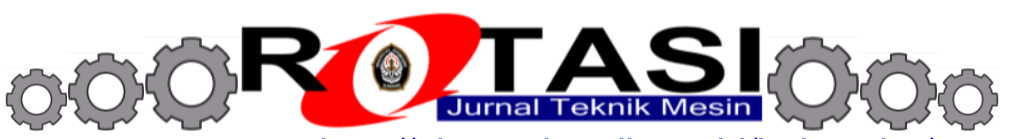

Available online at Website http://ejournal.undip.ac.id/index.php/rotasi

\title{
RANCANG BANGUN MODULAR FLOATING PONTOON FERROCEMENT SEBAGAI ALAT APUNG MULTIGUNA
}

\author{
*Aulia Windyandaria ${ }^{\mathrm{a}}$, Ahmad Fauzan Zakki ${ }^{\mathrm{b}}$ \\ ${ }^{a}$ Program Diploma Teknik Perkapalan, Fakultas Teknik, Universitas Diponegoro \\ Gedung Kuliah Bersama Lt.1 Fakultas Teknik Undip \\ bJurusan Teknik Perkapalan, Fakultas Teknik, Universitas Diponegoro \\ Gedung Program Diploma Fakultas Teknik Undip \\ *E-mail: auliaw@undip.ac.id
}

\begin{abstract}
Modular floating pontoon is a floating device commonly used as civil and marine construction. Pontoon is usually made of steel and high-density polyethylene (HDPE). Although the steel and HDPE has its own advantages and disadvantages in terms of economic, strength, and capacity. However the study of alternative raw materials for modular floating pontoon construction as multipurpose floating equipment is needed. Ferrocement which is familiar in the used for building construction material is an alternative material. Since the material is easy to find and it is such a versatile material that can be mass produced and has the mechanical strength that is simillar to steel and other materials. Following that condition the research is focused on the application of ferrocement technology for modular floating floating pontoon. The results show that the principal dimension of modular floating pontoon are length $80 \mathrm{~cm}$, width $80 \mathrm{~cm}$, height $75 \mathrm{~cm}$, with the lightweight draft of pontoons is $30 \mathrm{~cm}$. The material proportions for the modular floating pontoon are sand $48.2 \%$, cement $34.5 \%$ and water 17.3\%. Modular floating pontoon series consists of four Pontoons Square compiled with interlink (hook) so that the total of the package pontoon has a $160 \mathrm{~cm}$ long, $160 \mathrm{~cm}$ wide and $75 \mathrm{~cm} \mathrm{high}$.
\end{abstract}

Kata kunci: Modular floating pontoon, Ferrocement, Production process,

\section{PENDAHULUAN}

Ponton adalah perangkat apung yang memiliki daya apung yang cukup untuk mengapung sendiri serta dapat menanggung beban berat. Floating pontoon memiliki struktur fleksibel yang dapat diperpanjang oleh interlink floating ponton untuk membentuk sebuah platform memanjang seperti dermaga dan lainya. Pontoon yang biasa digunakan pada bidang industri atau konstruksi bangunan laut biasanya bahan dasar pembangunya dari baja atau fiber HDPE maupun material lainya, dan tentunya bahan- bahan tersebut memiliki kelebihan dan kekurangan tersendiri yang kemungkinan memiliki tingkat ketersediaan bahan baku kurang dan biaya yang cukup tinggi. Hal ini mendorong diperlukanya suatu penelitin mengenai alternatif bahan baku pembangun pontoon.

Dewasa ini kita kenal teknologi ferrocement, selain merupakan bahan baku serbaguna material ini mudah dijumpai dan dapat diproduksi masal. Struktur ferrocement mudah dikerjakan metode pembangunannya sangat sederhana serta memiliki keunggulan dari segi biaya, dan kekuatan yang tidak kalah dengan material lainya. Aplikasi teknologi ferrocement ini diterapkan dalam pembangunan modular floating pontoon sebagai suatu bentuk alternatif pembangunan alat apung multiguna.

\section{MATERIAL DAN METODOLOGI}

Sejarah perkembangan teknologi ponton sebagai alat apung dapat dilihat dari evolusi teknologi pontoon bridge. Berdasarkan catatan sejarah melalui buku shing chi jembatan pontoon pertama kali ditemukan pada abad kesebelas sebelum masehi. Namun berdasarkan sejarahwan Joseph Needham, jembatan ponton ditemukan sekitar abad kedelapan dan kesembilan sebelum masehi, [1]. Pada abad kelima sebelum masehi, jembatan ponton juga digunakan di masa pemerintahan kekaisaran Raja Darius untuk menghubungkan benua Asia dan Eropa di sungai Bosporus, [2]. Pada era modern, ponton banyak digunakan untuk kepentingan angkatan perang dan warga sipil dalam perang dunia. Jembatan ponton ini digunakan untuk memfasilitasi operasi militer. Selain itu di era modern, jembatan ponton juga banyak digunakan sebagai konstruksi jembatan untuk menghubungkan daerah yang terpisah oleh air. Empat dari lima jembatan ponton terpanjang di dunia terdapat di Washington.

Jembatan ponton memberikan gagasan untuk memperluas aplikasi modular pontoon sebagai alat apung multiguna, khususnya menjadi trotoar apung. Berdasarkan karakteristik ponton sebagai alat apung dan ide untuk membuat sarana apung yang terdiri dari modul-modul ponton yang dapat dibongkar pasang (knockdown system), trotoar apung (floating paving pontoon) akan dikembangkan untuk mendukung evakuasi bencana banjir.

Beberapa artikel telah direview untuk menunjang pengembangan desain modular floating paving pontoon (trotoar apung). Artikel-artikel ini mayoritas berhubungan dengan karakteristik ponton sebagai jembatan ponton atau 
very large floating structure (VLFS). Wu and Shih, [3] mempelajari getaran elastis dari floating bridge dengan beban bergerak (moving load), ponton dianggap sebagai balok ramping yang diletakkan pada pondasi elastis. Analisis respon hidroelastis dari jembatan ponton dalam kondisi gelombang dengan domain frekuensi, telah dilakukan oleh Ueda [4-6], Oka [7] dan Ikegami [8]. Ikegami telah memverifikasi solusi numerik dengan uji model elastis skala besar. Struktur jembatan ponton telah dimodelkan dengan menggunakan metode elemen hingga dan pengaruh fluida telah ditentukan dengan menggunakan metode elemen batas dalam lingkup teori linier. Untuk domain waktu Watanabe, [9] telah menganalisis perilaku hidroelastis dan perhitungan pengaruh memori terhadap redaman gelombang. Ertekin, [10] menganalisis respon hidroelastis jembatan ponton yang terkoneksi secara mekanis dengan beban bergerak dan statis, beban arus dan beban eksternal lainnya.

\subsection{Teknologi Ferrocement}

Ferrocement adalah suatu tipe dinding tipis beton bertulang yang dibuat dari mortar semen hidrolis diberi tulangan dengan kawat anyam / kawat jala (wire mesh) yang menerus dan lapisan yang rapat serta ukuran kawat relatif kecil. Anyaman ini bisa berasal dari logam atau material lain yang tersedia. Kehalusan dan komposisi matriks mortar seharusnya sesuai dengan sistem anyaman dan selimut (pembungkusnya). Jika didefinisikan secara sederhana, ferrocement adalah suatu tipe dinding tipis beton bertulang yang dibuat dari kawat jala, pasir, air, dan semen. Teknologi ferrocement pertama kali diajukan hak patennya oleh Joseph-Louis Lambot tahun 1852 di Prancis dengan membangun dua perahu tahun 1848 dan 1849.

Tahun 1940, Pier Luigi Nervi, insinyur arsitek Italia, menghidupkan kembali konsep ferrocement dengan membangun sebuah kapal untuk memancing. Setelah Perang Dunia II Nervi menunjukkan kembali kelebihan ferrocement dengan membangun kapal pancing 165 ton, diberi nama Irene, dengan dinding kapal ferrocement tebal 1,4 inch $(36 \mathrm{~mm})$ yang lebih ringan 5 persen dibandingkan menggunakan bahan kayu, dan biayanya pun 40 persen lebih murah.

Pada awal tahun 1960, akhirnya ferrocement dapat diterima secara luas untuk konstruksi kapal laut di Inggris, Selandia Baru, Kanada, dan Australia. Tahun 1968, FAO mengadakan proyek pembuatan kapal ferrocement di Asia, Afrika, Amerika Latin, dan Uni Soviet. Dibanding dengan beton bertulang, ferrocement memiliki sejumlah perbedaan. Dari segi fisik, ferrocement lebih tipis, memiliki tulangan yang terdistribusi pada setiap ketebalannya, penulangan dua arah, dan matriksnya hanya terdiri atas agregat halus dan semen. Dari sifat mekaniknya, ferrocement memiliki sifat-sifat seragam dalam dua arah, umumnya memiliki kuat tarik dan kuat lentur yang tinggi, memiliki ratio tulangan yang tinggi, proses retak dan perluasan retak yang berbeda pada beban tarik, duktilitas meningkat sejalan dengan peningkatan rasio tulangan anyam, kedap air tinggi. Ferrocement lemah terhadap temperatur tinggi, tetapi ketahanan terhadap beban kejut lebih tinggi. Metode pembuatannya pun berbeda dengan beton bertulang, tidak memerlukan keahlian khusus, sangat mudah dalam perawatan dan perbaikan, dan biaya konstruksi untuk aplikasi di laut lebih murah dibanding dengan kayu, beton bertulang, atau material komposit.

\subsection{Material Pembangunan Pontoon Ferrocement}

\subsubsection{Material Pasir}

Pasir yang digunakan adalah pasir sungai ex-lokal yang biasanya didapat dari tempat pengolahan agregat AMP (Asphalt Mixing Plant). Pasir yang digunakan merupakan pasir yang berasal dari partikel bebatuan yang terbawa oleh derasnya aliran sungai yang melewati sehingga deposit dari partikel bebatuan mengendap dan terbentuklah material pasir. Umumnya ukuran dan kandungan material pasir ini bervariasi tergantung dari daerah geolologis setempat. Ukuran pasir yang akan digunakan sebagai agregat halus untuk pembuatan ferrocement dalam penelitian ini adalah yang lolos ASTM (diambil diameter butiran $1-2 \mathrm{~mm}$ ). Untuk memperoleh agregat halus tersebut diperlukan proses pengayakan kembali dengan memproses pasir campuran (Pasir dari toko material/ produsen) menjadi agregat halus. Dari penelitian ini diketahui bahwa setiap $1 \mathrm{~m} 3$ pasir campuran (agregat halus + kerikil) terdiri dari $2 / 3$ agregat halus dan $1 / 3$ agregat kasar (kerikil).
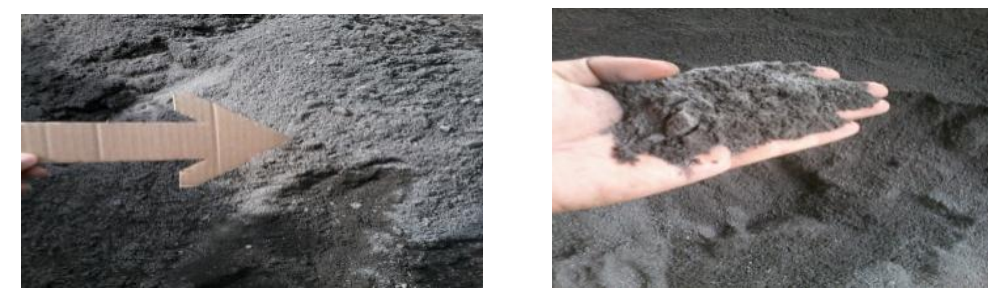

Gambar 1. Agregat halus pasir hasil pengayaan (diameter butiran $<1 \mathrm{~mm}$ )

\subsubsection{Material Semen}

Semen merupakan senyawa pengikat pada campuran mortar. Semen yang digunakan dalam penelitian ini adalah semen dari bahan klinker - semen - portland, yaitu semen yang sering digunakan sehari - hari dan dapat dicampur dengan senyawa yang lain. Semen Portland dibuat dari semen hidrolis yang dihasilkan dengan cara 
menghaluskan klinker yang terdiri dari bahan utama silikat kalsium yang bersifat hidrolis ditambah dengan bahan yang mengatur waktu ikat (umumnya gips). Klinker semen portland dibuat dari batu kapur $\left(\mathrm{CaCO}^{3}\right)$, tanah liat, dan bahan dasar berkadar besi.
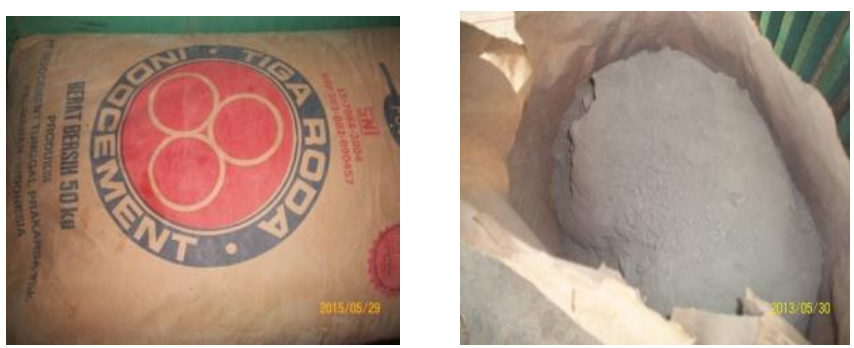

Gambar 2. Material semen (Semen Portland)

\subsubsection{Besi Cor (Reinforce Mesh)}

Merupakan tulangan berupa besi silinder panjang berukuran relatif kecil. Besi ini digunakan untuk memberikan kekuatan pada dinding-dinding pontoon ferrocement, dan menjadi kerangka pembentuk badan pontoon. Besi silinder ini dibentuk dan dirangkai dengan menyatukan besi satu dengan yang lainya menggunakan kawat besi sebagai pengikatnya. Material besi cor yang digunakan dalam penelitian ini adalah besi silender dengan diameter $6 \mathrm{~mm}$ dan panjang rata - rata setiap batang silinder $11-12 \mathrm{~m}$.
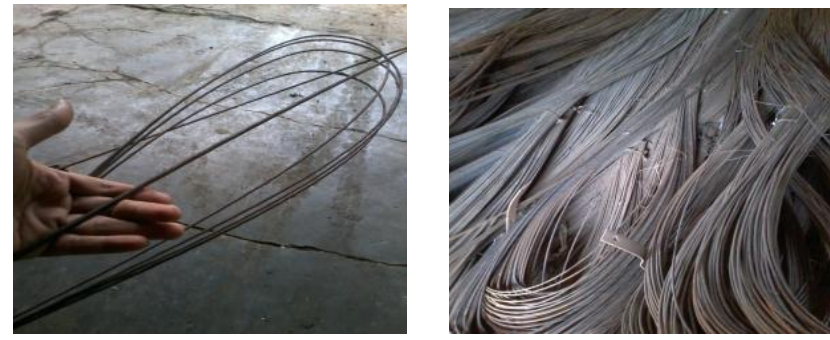

Gambar 3. Besi cor (Reinforce Mesh) ukuran diameter $6 \mathrm{~mm}$

\subsubsection{Kawat Anyam (Wire Mesh)}

Kawat Anyam / Wire Mesh merupakan lembaran kawat jala yang dianyam sedemikian rupa sehingga membentuk lembaran kawat anyam, material ini memberikan kekuatan tekan dan tarik pada rancang bangun pontoon. Dalam penelitian ini digunakan wire mesh anyaman segi empat yang banyak dijual di toko material bangunan dengan karakteristik diameter kawat penyusun $0,5 \mathrm{~mm}$, ukuran bukaan $1,25 \mathrm{~cm}$ x 1,25 cm
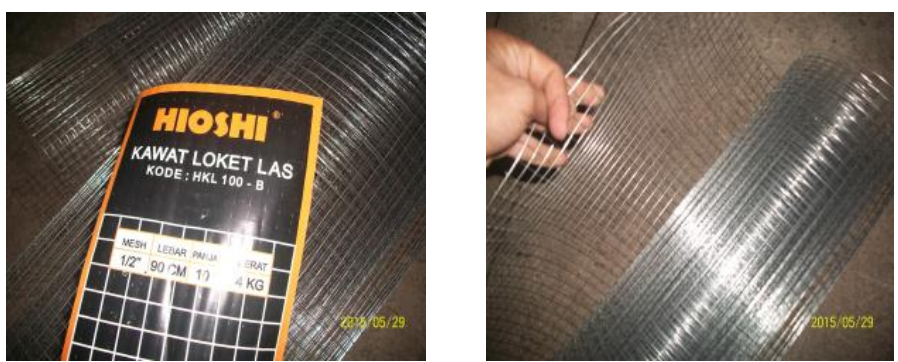

Gambar 4. Kawat anyam (Wire Mesh) $0,5 \mathrm{~mm}$, ukuran bukaan segi empat 1,25 x 1,25 츠

\subsubsection{Kotak Cetak (Material Bekisting)}

Bekisting atau kotak cetak adalah sebuah konstruksi yang dibuat dengan tujuan untuk menentukan bentuk dari konstruksi suatu beton maupun ferrocement, bekisting harus dapat dipasang secara sederhana, dilepas, dan dipindahkan. Dalam pelaksanaan penelitian digunakan dua material utama pembentuk bekisting, yaitu:

\section{Tripleks (Multipleks)}

Merupakan susunan sejumlah ganjil lapisan kayu finer yang direkatkan bersilang satu sama lain. Penggunaanya yang mudah dan dapat diaplikasikan dalam skala besar selain itu material ini dapat memberikan kerapatan dan permukaan yang baik, dalam penelitian ini digunakan multipleks ukuran panjang 2,44 m, lebar 1,22 m, dan tebal 2 $\mathrm{mm}$.

\section{Kayu Kerangka Bekisting}

Digunakan sebagai pembentuk kerangka bekisting, dianjurkan untuk pemilihan kerangka kayu ringan dan kuat. Dalam penelitian ini digunakan kayu randu ringan sebagai kerangka. 


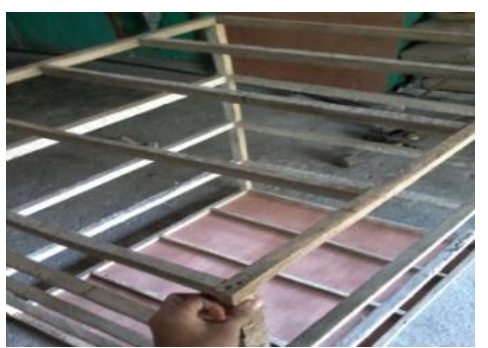

Gambar 5. kerangka kayu (kerangka bekisting)

\subsubsection{Kawat Besi (Kawat ikat)}

Sebagai material pengikat besi cor dengan material bahan besi yang ulet dan kuat. Dalam penelitian ini digunakan kawat besi ikat dengan diameter $1 \mathrm{~mm}$.

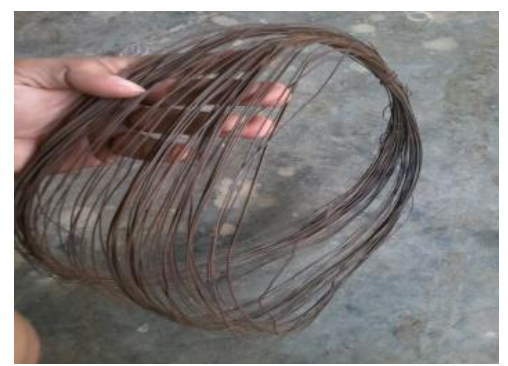

Gambar 6. Kawat Besi diameter $1 \mathrm{~mm}$

\subsubsection{Kimia Campuran (Admixtures)}

Merupakan suatu bahan material yang digunakan pada campuran adukan mortar (pasir, semen, air), sebagai bahan penguat dan pengeras material ferrocement. Material ini memiliki kegunaan sebagai pengeras dan penguat ,bahan kimia ini banyak sekali macamnya di industri bangunan.

\subsubsection{Air}

Karena pengerasan campran mortar berdasarkan campuran air dan seman, maka perlu dilakukan pemeriksaan terhadap air yang akan digunakan apakah telah memenuhi syarat-syarat tertentu. Jelas bahwa air tawar yang dapat diminum adalah air yang boleh dipakai, akan tetapi air minum tidak selalu ada sehingga perlu diperhatikan apakah air tersebut mengandung bahan yang dapat merusak beton atau ferrocement

\subsection{Karakteristik dan Material Ferrocement}

Ferrocement adalah struktural berkualitas tinggi yang bahan utamanya sederhana dan proses pembentukanya yang relatif mudah yang membuatnya dapat digunakan pada banyak konstruksi bangunan sesuai bentuk konstruksi yang diinginkan.

Dalam proses pembentukannya ferrocement terdiri dari beberapa macam material pembangun antara lain :

a. Reinforce and wire mesh

Merupakan tulangan berupa besi silinder panjang berukuran relatif kecil dan anyaman kawat jala (wire mesh). Biasanya wire mesh yang digunakan adalah berbentuk hexagonal watson dengan diameter kawat $0,5 \mathrm{~mm}$ dan jarak bukaan $1,5 \mathrm{~cm}$ x 2,5 cm.

b. Mortar ( Pasir, Semen, Air )

Mortar merupakan campuran material yang dipakai untuk membuat ferrocement,bahan material pembangunya adalah semen, pasir, dan air dengan komposisi tertentu. Dalam pembangunan mortar diusahakan tidak terguncang dan terlindung dari matahari dan hujan secara langsung. Komposisi mortar ferrocement yang digunakan biasanya adalah : Pasir : Semen : Air $=1,4: 1: 0,5$

\subsection{Metode Penelitian}

Secara umum penelitian ini terdiri dari 2 tahapan. Pada tahap pertama ditujukan untuk adalah perencanaan produksi mendapatkan proses produksi yang akan digunakan untuk menghasilkan produk modular floating pontoon. Pada tahap kedua dilakukan pengujian terhadap produk yang telah dihasilkan dari proses produksi yang telah direncanakan pada tahap pertama, pengujian dilakukan untuk melakukan tes kebocoran dan stabilitas pada ponton, serta untuk mengetahui bahwa ponton yang dibuat memiliki gaya angkat ke atas yang mampu menyanggah beban yang berada di atas geladak. . Untuk lebih jelas dapat dilihat pada diagram alir sebagai berikut: 


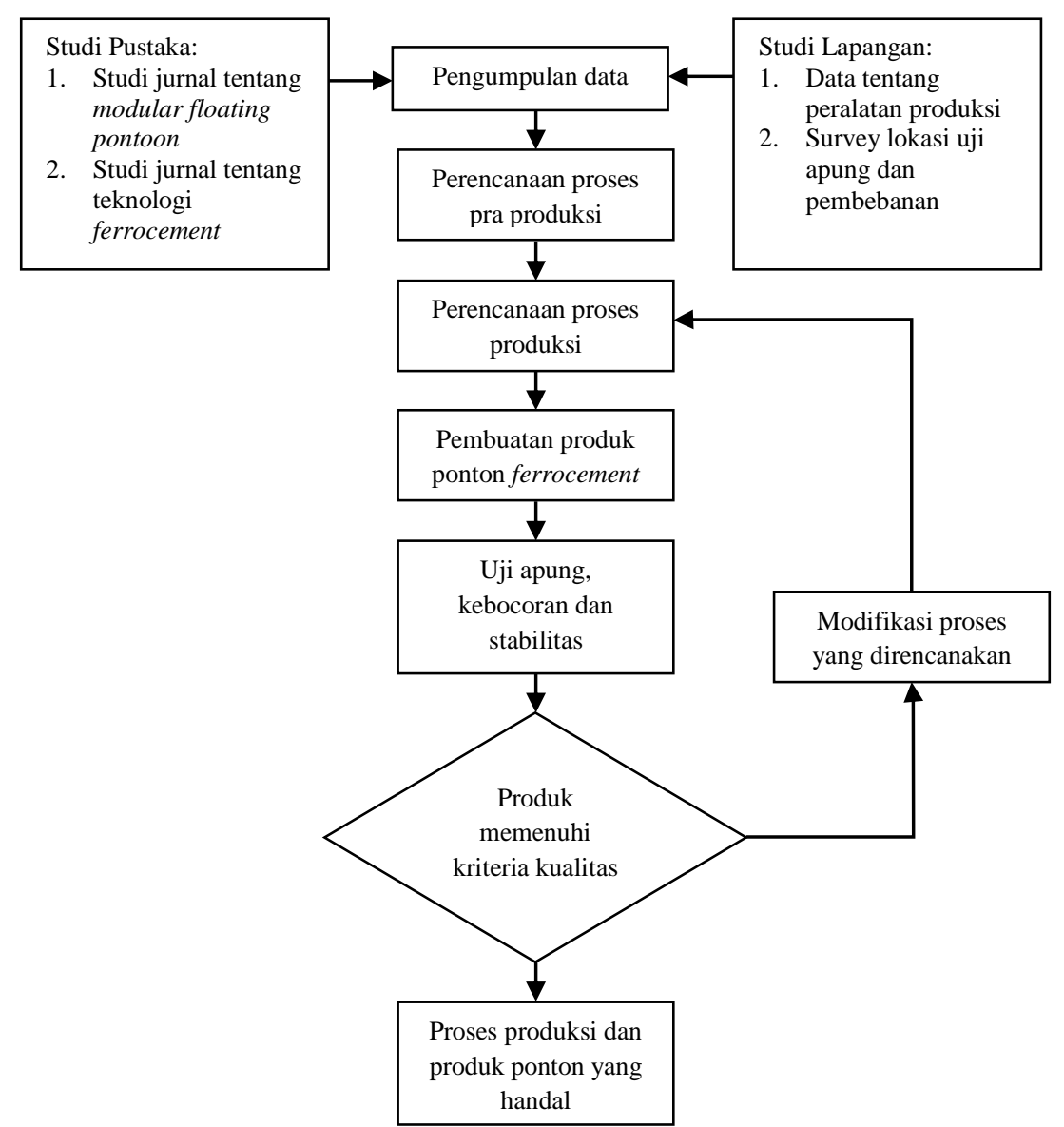

Gambar 7. Diagram alir metode penelitian

\section{HASIL DAN PEMBAHASAN}

\subsection{Perencanaan Model Pontoon}

Perencanaan Modular Floating pontoon Ferrocement ini dilaksanakan dengan menggunakan metode eksperimen. Pada metode ini dipakai beberapa variabel model pontoon sehingga diperoleh suatu model pontoon yang ingin dicapai. Adapun eksperimen dikerjakan dengan membangun tiga variasi model yang meliputi :

1. Model I, dengan dimensi ukuran $\mathrm{P} \times 1 \times \mathrm{t}=120 \mathrm{~cm}$ x $120 \mathrm{~cm}$ x $100 \mathrm{~cm}$ dengan tebal dinding keseluruhan $3 \mathrm{~cm}$, model ini diasumsikan sebagai model maksimum modul pontoon ferrocement yang akan dibangun.

2. Model II, dengan dimensi ukuran $\mathrm{P} \times 1 \times \mathrm{t}=80 \mathrm{~cm} \times 80 \mathrm{~cm} \times 75 \mathrm{~cm}$ dengan tebal dinding keseluruhan $2 \mathrm{~cm}$, model ini diasumsikan sebagai model minimum modul pontoon ferrocement yang akan dibangun, model ini ditentukan berdasarkan model sebelumnya (model I) yaitu merupakan 1/3 dari volume model I

Volume model I, $1,2 \mathrm{~m} \times 1,2 \mathrm{~m} \times 1,0 \mathrm{~m}=1,44 \mathrm{~m}^{3}$

Volume model II , $0,8 \mathrm{~m} \times 0,8 \mathrm{~m} \times 0,75 \mathrm{~m}=0,48 \mathrm{~m}^{3}$

3. Model III, dengan dimensi ukuran $\mathrm{P} \times 1 \times \mathrm{t}=0,8 \mathrm{~m} \times 0,8 \mathrm{~m} \times 0,75 \mathrm{~m}$ dengan tebal dinding alas $4 \mathrm{~cm}$ dan tebal dinding atas dan samping $2 \mathrm{~cm}$. Model ini diambil dengan berdasarkan model sebelumya yang sudah diuji dan memiliki draft apung yang cukup akan tetapi keseimbanngan yang sedikit kurang sehingga diasumsikan penambahan beban akan merubah titik M dan G sehingga keseimbangan model ini akan lebih baik.

\subsection{Perancangan Proses Produksi Ponton Ferrocement}

\subsubsection{Perencanaan tahap pra produksi}

Proses persiapan pada pembangunan ponton ferrocement ini dimulai dengan mempersiapkan seluruh material pembangun meliputi alat dan bahan, material bahan antara lain :

1. Pasir agregat halus dengan ukuran butiran maksimal $1-2 \mathrm{~mm}$

2. Semen portland sebagai bahan- ikat hidrolik dan merupakan bahan pembangun utama dalam proses pembangunan pontoon ferrocement.

3. Besi Cor dengan panjang rata - rata per batang $11-12 \mathrm{~m}$ dengan diameter $6 \mathrm{~mm}$.

4. Kawat anyam persegi dengan ukuran bukaan $1,25 \mathrm{~cm}$ x $1,25 \mathrm{~cm}$ dan diameter kawat $0,5 \mathrm{~mm}$, bentuk gulungan / lembaran dengan ukuran $0,9 \mathrm{~m} \times 10 \mathrm{~m}$.

5. Multipleks ukuran panjang $\mathrm{x}$ lebar $\mathrm{x}$ tebal $=2,44 \mathrm{~m} \mathrm{x} \mathrm{1,22} \mathrm{m} \times 2 \mathrm{~mm}$. 
6. Kayu bekisting (kayu randu), dibutuhkan kayu randu dengan ukuran penampang $3 \mathrm{~cm} \mathrm{x} 3 \mathrm{~cm}$.

7. Kawat ikat.

8. Kimia Campuran (admixtures) untuk percepat proses pengerasan

Peralatan yang digunakan :

1. Peralatan pekerjaan pembetonan seperti: ayakan, gergaji besi, pembengkok besi cor, cangkul / sekop, cethok besi, gergaji kayu, ember, tang, palu

2. Peralatan ukur dan dimensi, seperti: meteran, timbangan, penggaris siku

\subsubsection{Perencanaan Proses Produksi}

Proses pembuatan kotak cetak / bekisting, bekisting yang dikerjakan adalah bekisting tipe dalam / hilang, disebut sebagai bekisting hilang karena kotak cetak ini nantinya akan hilang tertanam di dalam pontoon ferrocement. Dipilih bekisting hilang ini dengan pertimbangan bahwa :

- Pengerjaan tidak bisa dilakukan dengan sistem cor karena dinding yang relatif tipis

- Membutuhkan ketelitian dalam pembuatan dinding - dinding tipis untuk menghindari adanya rongga atau crack, sehingga dilakukan secara manual.

Pembuatan kerangka bekisting menggunakan kayu ringan (dipilih kayu randu) dengan dimensi tulangan kayu tersebut 3 $\mathrm{cm}$ x $3 \mathrm{~cm}$ untuk lebar x tebalnya dan multipleks dengan tebal $2 \mathrm{~mm}$.

Pembuatan variasi bekisting dikerjakan untuk membuat suatu interlink, dibuatlah variasi bekisting sebagai pondasi interlink nantinya. Membuat tempat pondasi di setiap sudut dinding atas bekisting diambil tinggi $15 \mathrm{~cm} \mathrm{dan} \mathrm{p} \mathrm{x} 1=6 \mathrm{~cm}$ x $6 \mathrm{~cm}$

Proses pembuatan tulangan besi cor, digunakan besi silinder panjang, diameter $6 \mathrm{~mm}$. Besi ini dibengkokan dan dibentuk menggunakan mal besi cor dengan direncanakan tulangan besi ini akan tertanam ditengah - tengah semen. Yang harus diperhatikan dalam pembuatan tulangan besi yaitu tiap ujung / perpotongan besi cor harus dibuat pengait untuk memperkuat ikatan antar besi, dibuat pengait panjang $6 \mathrm{~cm}$. Kerangka tulangan besi bagian atas harus dalam keadaan terbuka karena nantinya akan digunakan untuk memasukan bekisting ke dalam kerangka tulangan besi.

Pemasangan kawat anyam (wire mesh), kawat anyam ini diikatkan di sekeliling tulangan besi menggunakan kawat ikat, diikatkan satu lapis kawat anyam ke seluruh permukaan kecuali bagian atas dipasang setelah tulangan bagian atas ditutup.

Proses cor dasar pada dinding alas pontoon, cor ini dikerjakan sesuai tebal dinding yang direncanakan. Sebelum melakukan pengecoran terlebih dahulu dipersiapkan adukan mortar (semen,pasir,air) dengan perbandingan 1 : 1,4 : 0,5 dan juga dipersiapkan bekisting untuk cetakan alas. Tujuan dilakukan cor dasar adalah :

- Untuk mendapatkan pondasi awal sebelum dilakukan proses plaster secara keseluruhan

- Cor dasar digunakan sebagai acuan ukuran utama pontoon.

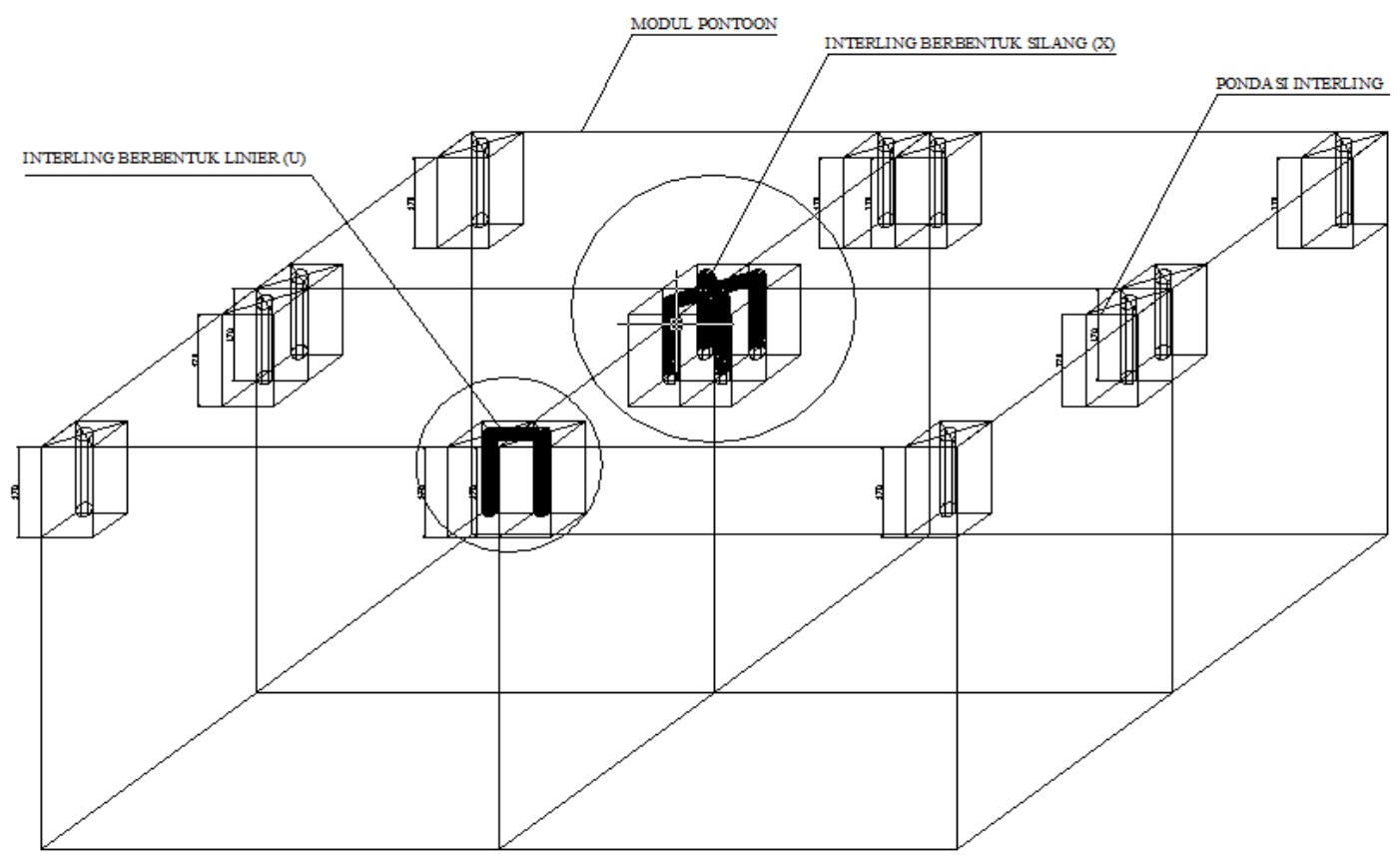

Gambar 8. Bentuk dan posisi interlink pada modul pontoon

Proses pemasangan bekisting kedalam kerangka tulangan besi. Setelah bekisting dipasang kemudian tulangan bagian atas ditutup dan juga dilapisi kawat anyam, sebelum ditutup seluruhnya, pada bagian pondasi interlink / 
pengait di keempat sudut atas diberi lapisan kawat anyam terlebih dahulu untuk memperkuat dan juga dipasangi pipa paralon ukuran diameter $2,5 \mathrm{~cm}$ sebagai lubang pengait nantinya. Tahap ini seluruh permukaan bekisting berada didalam lapisan kerangka tulangan besi dan wire mesh.

Proses plester dan finishing pada semua dinding pontoon dengan ketebalan yang telah direncanakan. Proses finishing terdiri dari dua pekerjaan antara lain :

- Proses pengacian yaitu pelapisan dinding ponton menggunakan campuran semen dan air lapisan tipis dengan tujuan memperoleh bentuk yang simetris dan halus. Proses ini dilakukan setelah plester cukup kering

- Proses pengecatan yaitu pelapisan dinding pontoon menggunakan cat anti air/ kedap air. Pengecatan dilakukan setelah acian cukup kering.

Proses pembuatan Interlink / pengait, pengait ini digunakan sebagai komponen untuk penggabung satu paket modul pontoon series, terbuat dari pipa besi diameter $2,25 \mathrm{~cm}$ yang dilas dan dibentuk terdiri dari dua buah bentuk pengait antara lain :

- Bentuk silang (x) dengan ukuran panjang silangan horisontal $12,5 \mathrm{~cm}$ dan vertikal $12 \mathrm{~cm}$

- Bentuk linier (U) dengan ukuran panjang horisontal 10,5 cm dan vertikal $12 \mathrm{~cm}$
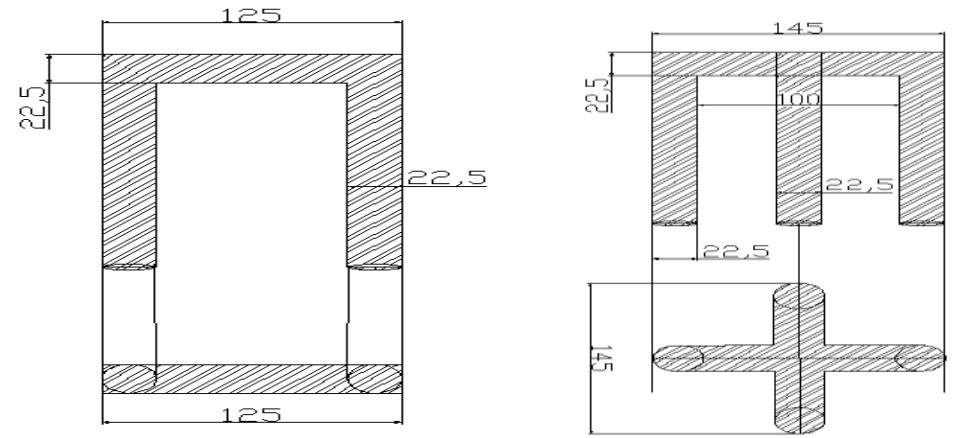

Gambar 9. Interlink berbentuk linier (U) dan silang (X)
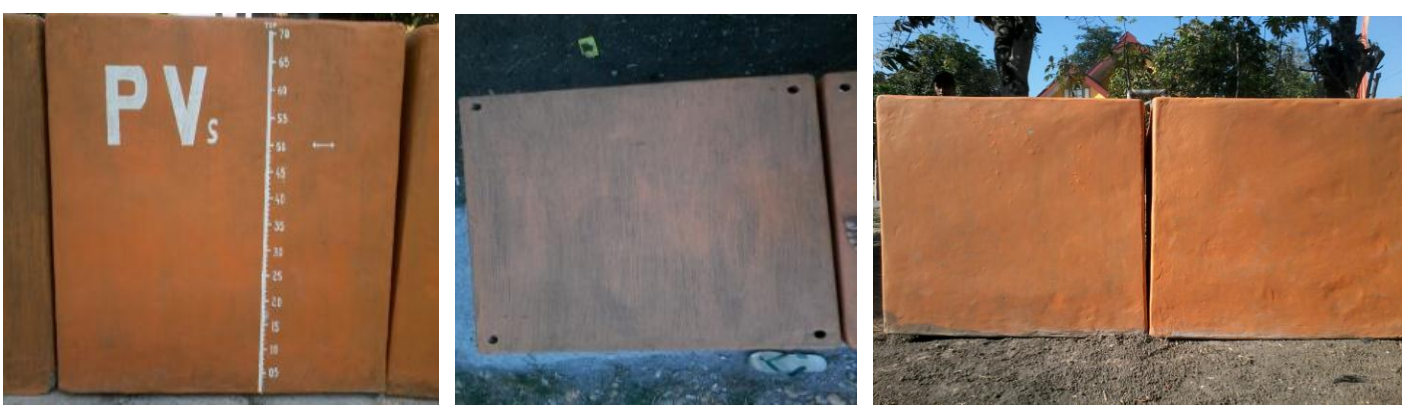

Gambar 10. Ponton tunggal tampak depan / samping
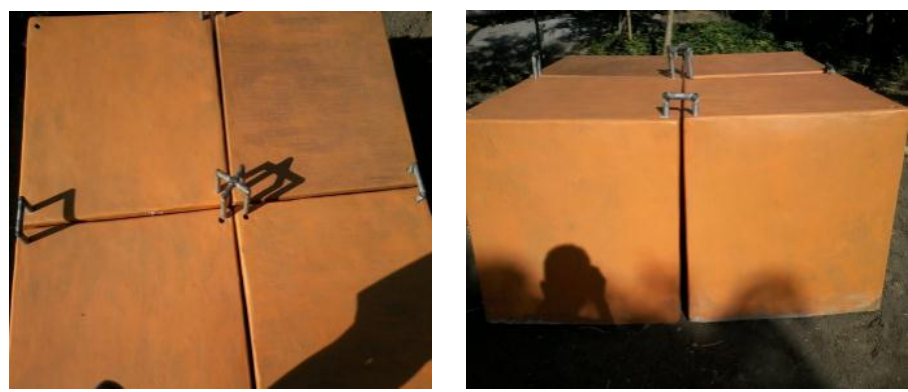

Gambar 11. Ponton Series (empat Pontoon)

Proses Pengujian Pengapungan dan Pembebanan, proses pengujian apung digunakan untuk mendapatkan karakteristik ponton pada saat di luncurkan ke dalam air. Selanjutnya dilakuakan uji pembebanan untuk mengetahui respon ponton apabila diberikan beban di geladaknya. Adapun hasil pengujian apung dan pembebanan adalah sebagai berikut:

Data hasil pengujian apung:

1. Percobaan ke-1, ukuran Pxlxt $=1,2 \mathrm{~m} \times 1,0 \mathrm{~m} \times 1,0 \mathrm{~m}$ dan tebal $3 \mathrm{~cm}$, memiliki Draft $=30 \mathrm{~cm}$

2. Percobaan ke-2, ukuran Pxlxt $=0,80 \mathrm{~m} \times 0,80 \mathrm{~m} \times 0,75 \mathrm{~m}$, dan tebal $2 \mathrm{~cm}$, memiliki Draft $=25 \mathrm{~cm}$

3. Percobaan ke-3, ukuran pxlxt $=0,80 \mathrm{~m} \times 0,80 \mathrm{~m} \times 0,75 \mathrm{~m}$, dan tebal alas $4 \mathrm{~cm}$,tebal samping $2 \mathrm{~cm}$ ), memiliki Draft $=30 \mathrm{~cm}$ 
Data hasil pengujian pembebanan dengan beban $60 \mathrm{~kg}$ :

1. P I (Percobaan ke-1), ukuran Pxlxt $=1,2 \mathrm{~m} \mathrm{x} \mathrm{1,2} \mathrm{m} \mathrm{x} \mathrm{1,0} \mathrm{m}$ dan tebal $3 \mathrm{~cm}$ ), memiliki Draft $=33 \mathrm{~cm}$

2. P II (Percobaan ke-2), ukuran Pxlxt = 0,80 m x 0,80 m x 0,75 m, dan tebal $2 \mathrm{~cm}$ ), memiliki Draft $=31 \mathrm{~cm}$

3. P III (Percobaan ke-3), ukuran pxlxt $=0,80 \mathrm{~m} \times 0,80 \mathrm{~m} \times 0,75 \mathrm{~m}$, dan tebal alas $4 \mathrm{~cm}$,tebal samping $2 \mathrm{~cm}$ ), memiliki Draft $=36 \mathrm{~cm}$

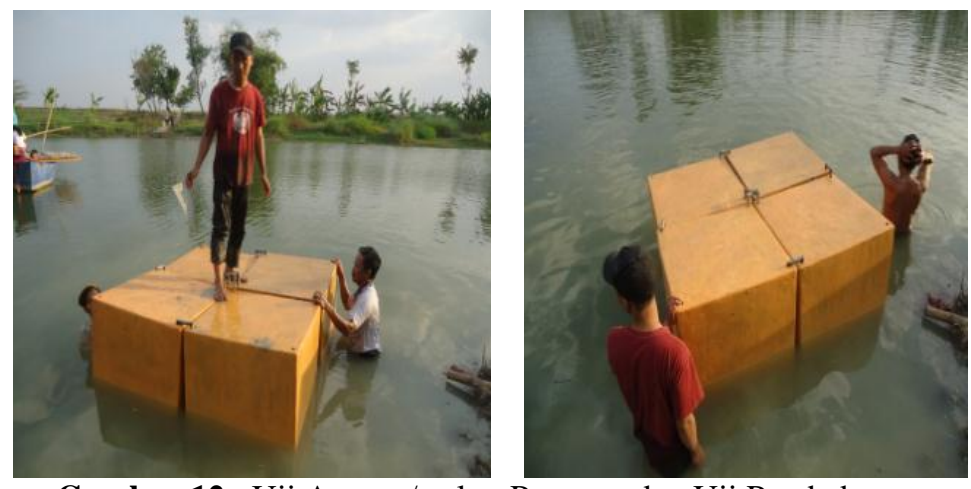

Gambar 12. Uji Apung / celup Pontoon dan Uji Pembebanan

\section{KESIMPULAN}

Berdasarkan hasil penelitian, dapat ditarik beberapa kesimpulan yaitu:

1. Berdasarkan percobaan yang telah dilakukan, diperoleh model dan prototype Modular floating pontoon ferrocement sebagai berikut:

- Model I, ukuran Pxlxt = 1,2 m x 1,2 m x 1,0 m dan tebal $3 \mathrm{~cm}$.

- Model II, ukuran Pxlxt = 0, $8 \mathrm{~m}$ x 0,8 $\mathrm{m}$ x 0,75 $\mathrm{m}$ dan tebal $2 \mathrm{~cm}$.

- Model III, ukuran Pxlxt = 0, $8 \mathrm{~m}$ x 0, $8 \mathrm{~m}$ x 0,75 $\mathrm{m}$ dan tebal alas dan atas $4 \mathrm{~cm}$, tebal samping $2 \mathrm{~cm}$

2. Berdasarkan Pengujian secara teknis didapat hasil sebagai berikut :

- Pontoon ferrocement Pxlxt = 1,2 $\mathrm{m}$ x 1,2 $\mathrm{m}$ x 1,0 $\mathrm{m}$ dan tebal $3 \mathrm{~cm})$, memiliki Draft $=30 \mathrm{~cm}$

- Pontoon ferrocement Pxlxt =0,8 m x 0,8 $\mathrm{m}$ x 0,75 $\mathrm{m}$ dan tebal $2 \mathrm{~cm}$, memiliki Draft $($ Sarat $)=25 \mathrm{~cm}$

- Pontoon ferrocement Pxlxt $=0,8 \mathrm{~m}$ x 0,8 $\mathrm{m}$ x 0,75 $\mathrm{m}$ dan tebal alas dan atas $4 \mathrm{~cm}$, tebal samping $2 \mathrm{~cm}$ ), memiliki Draft $=30 \mathrm{~cm}$

3. Dari percobaan tersebut didapat model yang optimal adalah dengan ukuran, Panjang : $78 \mathrm{~cm}$, lebar :78 cm, tinggi : $73 \mathrm{~cm}$, dan tebal $2 \mathrm{~cm}$ dan $4 \mathrm{~cm}$.

\section{REFERENSI}

[1] Anonymous, 2010. "The history of Herodotus - Volume 2 by Herodotus - Project Gutenberg" (http://www.gutenberg.org/etext/2456). Gutenberg.org. 2001-01-01. Retrieved 2010-09-02.

[2] Wu JS, Shih PY. Moving-load-induced vibrations of a moored floating bridge. Computers and Structures 1998;66(4):435-61.

[3] Ueda S, Oka S, Kumamoto N, Inoue K, Seto H, 1996. Design procedures and computational analysis of motions and deformations of floating bridge subjected to wind and waves. In: Proc. of the Third Asian-Pacific Conference on Computational Mechanics.

[4] Ueda S, Seto H, Kumamoto N, Inoue K, Oka S., 1996. Behavior of floating bridge under wind and waves. In: Proc. of the international workshop on very large floating structures.

[5] Ueda S, Maruyama K, Ikegami K, Seto H, Kumamoto N, Inoue K, 1989. Experimental study on the elastic response of a movable floating bridge in waves. In: Proc. of the international workshop on very large floating structures.

[6] Oka S, Kumamoto K, Inoue K, Ikegami K, Seto H, Ueda S, 2000. Elastic response analysis method for floating bridges in waves. Mitsubishi Technical Review 2000;37(2).

[7] Ikegami K, Kumamoto N, Inoue K, Oka S, Seto H, Ueda S, 2001. Elastic response of floating bridge in waves. In: Proc. of the 20th International Conference on Offshore Mechanics and Arctic Engineering, OMAE'01, Rio de Janeiro, NJ, Brazil; 2001. OMAE2001/OSU-5151.

[8] Watanabe E, Utsunomiya T, Murakoshi J, Fumoto K, Tanaka H, Nagata S, 2003. Development of dynamic response analysis program for floating bridges subjected to wind and wave loadings. In: Proc. Int. Sym. on Ocean Utilization Technology; Jan. 28-31, 2003. Tokyo, Japan.

[9] Ertekin RC, Riggs HR, Kim JW, Demirbilek Z. Hydroelastic analysis of floating bridges in current. OMAE2001/OSU-5029. 